\title{
Transformation of Glucocorticoid and Progesterone Receptors to the DNA-Binding State
}

\author{
William B. Pratt \\ Department of Pharmacology, University of Michigan Medical School, Ann Arbor, \\ Michigan 48109
}

This brief review explores some recent observations relating to the structure of untransformed glucocorticoid and progesterone receptors and the mechanism by which the receptors are transformed to the DNA-binding state. In their molybdatestabilized, untransformed state, progesterone and glucocorticoid receptors exist as a heteromeric 8-9S complex containing one unit of steroid binding phosphoprotein and one or two units of the $90 \mathrm{kD}$ heat shock protein hsp 90 . When the receptors are transformed, the steroid-binding protein dissociates from hsp90. In cytosol preparations, temperature-mediated dissociation proceeds much more rapidly in the presence of hormone. The dissociated receptor binds to DNA with high affinity, regardless of whether it is in the hormone-bound or the hormone-free state. These observations raise the possibility that the primary, and perhaps the only, role for the hormone is to promote dissociation of the receptor-hsp90 complex.

Molybdate, vanadate, and tungstate inhibit receptor transformation to the DNA-binding form, an effect that appears to reflect the ability of these transition metal oxyanions to stabilize the complex between the steroid receptor and hsp90. By promoting the formation of disulfide bonds, hydrogen peroxide also stabilizes the glucocorticoid receptor-hsp90 complex and prevents receptor transformation. A small, heat-stable factor present in all cytosol preparations inhibits receptor transformation, and, when the factor is removed, glucocorticoid receptors are rapidly transformed. This ubiquitous factor has the physical properties of a metal anion, and it is proposed that molybdate and vanadate affect steroid receptor complexes by interacting with a metal anion-binding site that is normally occupied by this endogenous receptor-stabilizing factor.

Key words: steroid receptors, heat shock protein, transformation, phosphorylation

When steroid-bound receptors in cell-free lysates are exposed to increases in temperature, ionic strength, or $\mathrm{pH}$, the receptors are transformed from a non-DNAbinding state to a form that binds to nuclei, DNA, and a variety of polyanions [1]. For a long time, analysis of the structure of the untransformed, non-DNA-binding 
state of glucocorticoid and progesterone receptors was compromised by the fact that the procedures employed for analysis of receptor structure promote receptor transformation. The study of the transformation process was facilitated when it was shown that molybdate, a transition metal oxyanion known to stabilize the steroid-binding activity of unoccupied glucocorticoid receptors [2], could reversibly inhibit transformation of steroid-bound receptors [3,4; see 5,6, for reviews].

Several laboratories have examined the structure of molybdated-stabilized glucocorticoid receptors by molecular sieve chromatography and sucrose gradient centrifugation. It was established that glucocorticoid receptors that are stabilized in their untransformed state exist in cytosol preparations as oligomeric complexes with an apparent $\mathrm{M}_{\mathrm{r}}$ of about 300,000 , and that, during transformation to the DNA-binding state, the receptor undergoes a reduction in size to an apparent $M_{r}$ of $94,000-100,000$ [7-9]. The untransformed complex is the 8-9S complex, and the dissociated, transformed state is the classic $4 \mathrm{~S}$ form of the receptor.* Careful analysis of the size of molybdate-stabilized receptors for other steroids $[6,10,11]$ has led to a general model in which the untransformed receptor exists in cytosol preparations as a large oligomeric complex and the DNA-binding form is the dissociated receptor protein. Holbrook et al [7] have shown that glucocorticoid receptors that were transformed in intact cells and subsequently analyzed in the presence of molybdate sediment at about $4 S$, whereas untransformed receptors sediment at $9 S$ under the same conditions. This suggests that transformation in intact cells is also accompanied by a reduction in receptor size and that molybdate may be stabilizing a physiologically relevant complex.

\section{PURIFICATION OF UNTRANSFORMED RECEPTORS}

When affinity resins for steroid receptor isolation were developed in the early $1980 \mathrm{~s}$, several investigators used the technique to purify the untransformed, molybdate-stabilized form of progesterone and glucocorticoid receptors. In the case of both the progesterone receptor from the chick oviduct $[12,13]$ and the glucocorticoid receptor from mouse L cells [14] or rat liver [15], the major protein that was purified was an $85-92 \mathrm{kD}$ (now referred to as $90 \mathrm{kD}$ ) protein. The purified progesterone $[12,13]$ and glucocorticoid $[15,16]$ receptors sedimented as $8-9 \mathrm{~S}$ complexes in the presence of molybdate, and, after withdrawal of molybdate, they dissociated to $4 \mathrm{~S}$ complexes in the presence of salt. Because the $90 \mathrm{kD}$ protein was not recovered when cytosol was preincubated with steroid in order to occupy receptor sites prior to adsorption with the affinity resin $[14,15,17]$, it was assumed that the $90 \mathrm{kD}$ protein was the steroid-binding protein.

Subsequently, when radiolabeled, site-specific affinity ligands were used to identify the steroid-binding component of the purified molybdate-stabilized progesterone receptor complex, it became clear that the $90 \mathrm{kD}$ protein was not labeled. In the case of the chick oviduct, two proteins were labeled with the progesterone analog

\footnotetext{
*In this review, I refer to the untransformed molybdate-stabilized glucocorticoid and progesterone receptor complexes as migrating at $9 \mathrm{~S}$ on sucrose gradient centrifugation and the dissociated state of the receptors as migrating at $4 \mathrm{~S}$. Various authors have utilized more specific values (eg, 9.2S, $8 \mathrm{~S}, 4.5 \mathrm{~S}$, $3.8 \mathrm{~S}$ ) based on analysis with their own systems, but, for the purposes of this discussion, such distinctions are not necessary.
} 
$\left[{ }^{3} \mathrm{H}\right] \mathrm{R} 5020$, one that migrated on gel electrophoresis under denaturing conditions at approximately $80 \mathrm{kD}$ and another that migrated at about $110 \mathrm{kD}[17,18]$. These steroid-binding proteins correspond, respectively, to the A and B peptides characterized previously on purification of the transformed progesterone receptor from chick oviduct [19]. Affinity purification of the molybdate-stabilized rabbit uterine progesterone receptor yielded 85 and $120 \mathrm{kD}$ steroid-binding proteins and a $90 \mathrm{kD}$ nonsteroid-binding protein [20].

Careful examination of the purified molybdate-stabilized receptor from mouse L cells and WEHI-7 thymoma cells revealed a $100 \mathrm{kD}$ protein that was labeled with the affinity ligand $\left[{ }^{3} \mathrm{H}\right]$ dexamethasone 21 -mesylate and a $90 \mathrm{kD}$ nonsteroid-binding phosphoprotein $[21,22]$. Although it is clear that most of the $90 \mathrm{kD}$ material purified from molybdate-stabilized rat liver cytosol is not a steroid-binding protein [16], it has proved difficult to resolve clearly the nonsteroid-binding component from the intact rat liver glucocorticoid-binding protein, which migrates close to it at $94 \mathrm{kD}$ [23].

\section{EVIDENCE THAT THE 90 kD PROTEIN IS A COMPONENT OF 9S RECEPTOR COMPLEXES}

The $90 \mathrm{kD}$ protein can be clearly differentiated from the progesterone- and glucocorticoid-binding proteins on the basis of its immunoreactivity. Radanyi et al [24] prepared a monoclonal antibody (BF4) to the purified, molybdate-stabilized chicken oviduct progesterone receptor and showed that it reacted with the $90 \mathrm{kD}$ nonsteroid-binding protein but not with the $80 \mathrm{kD}$ or the $110 \mathrm{kD}$ progesterone-binding proteins [25]. Similarly, antiserum raised against the purified $110 \mathrm{kD}$ progesteronebinding protein recognizes the 80 and $110 \mathrm{kD}$ steroid-binding peptides but not the 90 $\mathrm{kD}$ peptide [26]. Sullivan et al [27] have also prepared several monoclonal antibodies against the progesterone receptor-associated $90 \mathrm{kD}$ protein from chick oviduct. None of these antibodies bind to the transformed $4 \mathrm{~S}$ form of the progesterone receptor, but two of them bind to the untransformed 9S complex. Importantly, the BF4 antibody of Radanyi et al [24] has been demonstrated to react with (shift the sedimentation velocity of) molybdate-stabilized estrogen, androgen, and glucocorticoid receptor complexes in chick oviduct cytosol [28] and mineralocorticoid receptors in cytosol from chick colon [29]. Similarly, the CB1 antibody of Sullivan et al [27] was shown to react with untransformed androgen and glucocorticoid receptors in chick oviduct cytosol.

When untransformed glucocorticoid receptors are immunopurified (by adsorption to protein A-Sepharose) from molybdate-stabilized cytosol using monoclonal antibodies specific for the $100 \mathrm{kD}$ steroid-binding protein, the $90 \mathrm{kD}$ nonsteroidbinding protein is also absorbed in an immunospecific manner [21,22]. Immunoadsorption of transformed receptors does not result in isolation of the $90 \mathrm{kD}$ protein $[22,30-32]$. The $90 \mathrm{kD}$ protein is clearly a component of the $9 \mathrm{~S}$ receptor complex; immunoadsorption of the isolated $9 \mathrm{~S}$ complex from $\mathrm{L}$ cells with antibody specific for the $90 \mathrm{kD}$ protein results in the immunospecific adsorption of the $100 \mathrm{kD}$ glucocorticoid-binding protein [33].

All of these observations have led to a general model in which the molybdatestabilized, untransformed state of glucocorticoid and progesterone receptors contains a $90 \mathrm{kD}$ nonsteroid-binding protein in addition to a steroid-binding protein. Given that antibodies against the $90 \mathrm{kD}$ protein shift the sedimentation velocity of other 
receptors, it is likely that the $90 \mathrm{kD}$ protein is a component of untransformed estrogen, androgen, and mineralocorticoid complexes as well.

It is of considerable interest that, in the presence of molybdate, the receptor for the fungal sex steroid pheromone antheridiol in cytosol of Achlya ambisexualis male cells has a sedimentation coefficient of $8 \mathrm{~S}$ [34]. As with other steroid receptors, the $8 \mathrm{~S}$ form can be converted to the $4 \mathrm{~S}$ form by salt treatment [35]. Riehl et al [36] have purified an $88 \mathrm{kD}$ protein that is associated with the molybdate-stabilized antheridiolbinding protein and prepared a monoclonal antibody called AC88. This AC88 antibody recognizes an epitope common to a $90 \mathrm{kD}$ protein present in cytosols prepared from a wide range of tissues obtained from a number of avian and mammalian species [36]. The observations made on fungal antheridiol receptors suggest that the association of steroid-binding proteins with the $90 \mathrm{kD}$ protein has been conserved throughout evolution of eukaryotes from fungi to the highly evolved mammals. The fact that AC88 antibody recognizes an epitope that is conserved in $90 \mathrm{kD}$ proteins present in cytosols prepared from all vertebrate tissues tested suggests that the $90 \mathrm{kD}$ protein is ubiquitous and essential to cell function.

\section{THE 90 kD PROTEIN ASSOCIATED WITH STEROID RECEPTORS IS A HEAT SHOCK PROTEIN}

By 1985 , several facts about the $90 \mathrm{kDa}$ receptor-associated protein were known. 1) As noted above, it contains a region that is conserved in $90 \mathrm{kD}$ proteins that are widely distributed in vertebrate tissues [27,36,37]. 2) It is phosporylated on serine residues by intact cells $[14,21,22,38,39]$. 3) It is located largely in the cytoplasm as shown by immunohistochemical analysis [37]. 4) It is an abundant protein in cytosol preparations $[30,36,40]$. These characteristics taken together are descriptive of the $90 \mathrm{kD}$ heat shock protein $[41,42]$, so hsp90 was considered a likely candidate for the receptor-associated protein. Accordingly, three laboratories working with the receptor-associated $90 \mathrm{kD}$ protein (the laboratories of Toft, Baulieu, and Pratt) formed collaborations with laboratories working with hsp90 (those of Brugge, Feramisco, and Schlesinger, respectively) to determine if the $90 \mathrm{kD}$ receptor-associated protein is hsp 90 .

Identity of the progesterone receptor-associated $90 \mathrm{kD}$ protein of chick oviduct was established by several criteria $[40,43]$. 1) The receptor-associated protein was shown to have the same peptide map as hsp90. 2) Monoclonal antibody directed against hsp90 recognized the receptor-associated protein in immunoblot assay. 3) Anti-hsp90 antibody caused a shift in the sedimentation of the molybdate-stabilized receptor. 4) A monoclonal antibody against the receptor-associated protein recognized a $90 \mathrm{kD}$ protein whose rate of synthesis increased when chick embryo fibroblasts were heat shocked. Similarly, the glucocorticoid receptor-associated $90 \mathrm{kD}$ protein of $\mathrm{L}$ cell cytosol was shown to react on immunoblot assay with antibody raised against purified chicken heat shock protein [30,31], and the same antibody was used to immunoadsorb the $100 \mathrm{kD}$ glucocorticoid-binding protein from the isolated molybdate-stabilized 9S complex [33].

Taken together, these observations provide strong evidence that untransformed progesterone and glucocorticoid receptors are associated with hsp90 in a heterooligomeric 9S complex. The stoichiometry of the components is not yet firmly established. Okret et al [44] have provided good evidence that the molybdate-stabilized rat 
liver glucocorticoid receptor complex contains only one molecule of the steroidbinding protein. Renoir et al [17] have employed a cross-linking technique to examine the molybdate-stabilized progesterone receptor purified from chick oviduct cytosol, and they suggest a stoichiometry of one molecule of steroid-binding protein to two molecules of hsp90. It is tempting to add up the molecular masses involved to try to account for a 9S complex. For the glucocorticoid receptor, for example, one steroidbinding progein and two units of hsp90 would yield a complex of $\mathrm{M}_{\mathrm{r}}$ about 280,000 , which is close to several estimates for the mass of the molybdate-stabilized receptor [7-9]. It should be emphasized, however, that there is no proof for such a composition, and other, as yet unidentified components could exist in the heteromeric, untransformed receptor complex.

\section{DISSOCIATION OF THE RECEPTOR FROM hsp90 DURING TRANSFORMATION}

The fact that hsp90 has been recovered in association with the untransformed, 9S, non-DNA-binding form of progesterone and glucocorticoid receptors but not in association with the $4 \mathrm{~S}$, DNA-binding form suggests that dissociation of receptor from hsp90 is critical for generating the DNA-binding state. Several observations support the proposal that dissociation from hsp90 is closely linked to and perhaps sufficient for generating transformed receptor. The observation of Mendel et al [22] that hsp90 is not associated with glucocorticoid receptors that have undergone steroiddependent transformation in intact mouse thymoma cells (whereas it is readily recovered in association with untransformed receptors) provides evidence that dissociation is relevant to hormone-dependent events as they occur in intact cells.

Most of the information regarding dissociation of receptor from hsp90 has been generated in cell-free lysates. When $\mathrm{L}$ cell cytosol is incubated at $25^{\circ} \mathrm{C}$ in the absence of molybdate, receptors are transformed to the DNA-binding state, they are converted from the $9 S$ to the $4 S$ form, and they dissociate from hsp90. As was demonstrated by Sanchez et al [32], temperature-mediated transformation, 9S to $4 \mathrm{~S}$ conversion, and dissociation from hsp90 are all hormone-promoted events in that they proceed much more rapidly under hypotonic conditions when the receptor is bound by glucocorticoid. Correspondingly, Renoir has demonstrated that it is very difficult to separate untransformed, RU486-bound rabbit progesterone receptors from hsp90, regardless of whether the liganded receptor is exposed to elevated temperature or salt (J.-M. Renoir, personal communication). It is possible that the physiological action of RU486, which in many systems is a pure progesterone and glucocorticoid antagonist $[45,46]$, can be explained by its failure to permit receptor dissociation from hsp90. Indeed, RU486 appears to increase the affinity of the receptor for the large$\mathrm{M}_{\mathrm{r}}$ complex in rabbit uterine cytosol.

At this point, one might ask what is the role of the steroid in glucocorticoid hormone action? Traditionally, it has been thought that steroid must be bound to the receptor for the receptor to be biologically active. It is possible, however, that the only role played by the steroid in the sequence of events leading to high-affinity association of receptors with nuclear "acceptor" sites in the cell is to permit temperature-mediated receptor transformation. If, as I have indicated in the model shown in Figure 1, dissociation of the receptor from hsp90 is sufficient for transformation to the DNA-binding state, then hormone-free receptors that have been separated from 


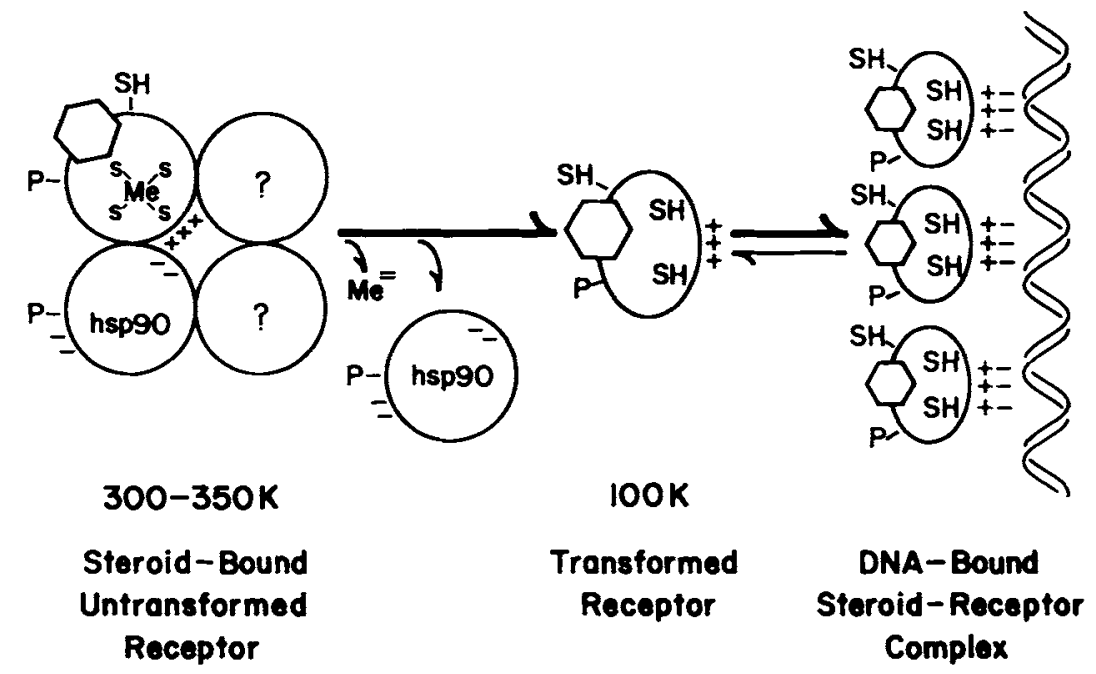

Fig. 1. Model illustrating the components of untransformed and transformed glucocorticoid receptor and the dissociation of the subunits during transformation. The receptor-bound steroid is indicated by the hexagon on the phosphoprotein containing the metal-binding site. The $9 \mathrm{~S}$ untransformed complex contains one unit of the glucocorticoid-binding phosphoprotein and one or two units of the $90 \mathrm{kD}$ heat shock protein hsp90. The open circles with question marks indicate that there might be other, as yet unidentified components in the untransformed complex. The presence of a metal anion ( $\mathrm{Me}^{2-}$ )-binding site is indicated in the steroid-binding protein. Both the endogenous inhibitor of transformation and the transition metal oxyanions molybdate and vanadate may interact at this site to maintain the receptor in high-affinity association with hsp90. During transformation, the steroid-binding protein dissociates from hsp90, resulting in exposure of the DNA-binding domain. The presence of sulfhydryl groups (SH) is to indicate that SH moieties are absolutely required for the glucocorticoid receptor to bind steroid and for the transformed receptor to bind to DNA. Different SH groups are required for steroid binding and DNA binding, and that is indicated in the model. (Reproduced from Meshinchi et al [92] with permission of the publisher.)

hsp90 should bind to DNA. The hsp90-receptor complex is readily dissociated with salt, and the resulting dissociated glucocorticoid receptor is precipitated at $30-35 \%$ ammonium sulfate [47]. In contrast, hsp90 does not precipitate until ammonium sulfate is present at $60-70 \%$ of saturation. When ammonium sulfate $(40-50 \%)$ is added to $\mathrm{L}$ cell cytosol containing hormone-free glucocorticoid receptors in the absence of molybdate, the receptor dissociates from hsp90 and it precipitates, leaving all the hsp90 in the supernatant [32]. The redissolved hormone-free receptor binds very tightly to DNA-cellulose. Indeed, we see no difference between hormone-free and steroid-bound receptor with regard to DNA-binding affinity.

Willmann and Beato [48] have recently shown that the steroid-free glucocorticoid receptor of rat liver binds selectively to hormone regulatory elements (HRE) in the long terminal repeat (LTR) region of mouse mammary tumor virus (MMTV) DNA. Bailly et al [49] have demonstrated that HRE sites located upstream from the start site of the rabbit uteroglobin gene are occupied with similar affinity by purified rabbit uterine progesterone receptors regardless of whether the receptors are hormone-free, or complexed with agonist, or complexed with the antagonist RU486.

Taken together, these observations suggest that the steroid is not required for DNA binding by the receptor once it is dissociated from the other components of the 9S cytosolic complex. In vivo, the hormone is clearly required to produce a hormone 
response, and it has been shown by the genomic footprinting technique to be required for protein-DNA interactions that occur at a glucocorticoid response element (GRE) [50]. It has not be demonstrated, however, that the hormone must be bound to the receptor for the receptor to interact appropriately with high-affinity nuclear "acceptor" sites and modulate gene transcription. Indeed, it is possible that in intact cells the receptor-mediated effects of glucocorticoids and progestins follow as a consequence of a steroid-dependent dissociation of the receptor from an hsp90-containing structure(s) that serves to keep the receptor from association with "acceptor" sites in the absence of hormone.

Now that techniques are available to identify receptors in the absence of ligand, it has become clear that hormone-free glucocorticoid receptors undergo some transformation when cytosol preparations are incubated at $25^{\circ} \mathrm{C}$. It had not been possible to detect this transformation previously because the unbound receptors lose their steroid-binding capacity when dissociation occurs. With immunoblot experiments [32] and with the DNaseI footprinting technique [48], it has been shown that some unoccupied receptor is converted to the DNA-binding form on incubation of cytosol at $25^{\circ} \mathrm{C}$. Thus, under cell-free conditions in cytosol preparations, the glucocorticoid does not act as an absolute switch to permit a receptor transformation that cannot occur in its absence. Rather, the hormone seems to increase markedly the rate of the temperature-dependent dissociation process. The rate at which receptor dissociation and generation of the DNA-binding state occurs in the absence of steroid seems to vary somewhat from one system to another. In mouse $\mathrm{L}$ cell cytosol, for example, hormone-free transformation occurs very slowly [32], but in rat liver cytosol it occurs considerably more rapidly [48] (also, work in progress by Bresnick and Pratt).

\section{RECEPTOR PHOSPHORYLATION IN RELATION TO RECEPTOR TRANSFORMATION}

As the change in sedimentation value of the receptor from $9 \mathrm{~S}$ to $4 \mathrm{~S}$ and dissociation of receptor from hsp 90 are both promoted by glucocorticoid when cytosol is warmed at $25^{\circ} \mathrm{C}$, the binding of the steroid must somehow reduce the affinity of the receptor for association with other components of the complex. In cytosol preparations, the effect of the steroid is not simply to change an equilibrium; the untransformed $9 \mathrm{~S}$ complex is not generated from the $4 \mathrm{~S}$ transformed state on elimination of steroid. The experiments of Raaka and Samuels [51] suggest that untransformed receptors are rapidly generated from transformed receptors in intact cells incubated at $37^{\circ} \mathrm{C}$. The unidirectional nature of the transformation process in cytosol preparations may suggest that some component of the $9 \mathrm{~S}$ complex is limiting such that reassociation cannot occur. It is also possible that the receptor has undergone some covalent change that makes it unable to reassociate.

Both glucocorticoid [14,21,22] and progesterone receptors [17,38,52,53] are naturally phosphorylated in intact cells, and several laboratories have suggested that transformation of the receptor to the DNA-binding form may require its dephosphorylation [1,54-57]. There are examples in which the DNA-binding activity of DNAbinding proteins is affected by phosphorylation [see, eg, 58,59], but the data available suggest that a change in phosphorylation state is not required for generation of a DNA-binding form of either glucocorticoid or progesterone receptors. 
Smith et al [60] have carefully examined both the size and the pI of glucocorticoid receptors from IM-9 human lymphoblasts to determine if transformation involves covalent charge modification. The $\left[{ }^{3} \mathrm{H}\right]$ dexamethasone-labeled steroid-binding protein of IM-9 cells resolves into two isoforms of identical mass. After transformation, there is no change in the apparent $\mathrm{pI}$ of either isoform, indicating that there is no covalent charge modification of the glucocorticoid-binding protein. It has been reported that treatment of untransformed glucocorticoid receptors with alkaline phosphatase promotes transformation [56,57], an effect that could reflect an action of the enzyme on the steroid-binding protein, on hsp90, or perhaps on other components of cytosol. Smith et al [60] have treated immunoadsorbed IM-9 receptor with alkaline phosphatase and found no change in the pI of either isoform of the steroid-binding protein. It is interesting that, after thermal transformation, only the more basic of the two steroid-binding protein isoforms binds to DNA-cellulose.

Mendel et al [61] and Tienrungroj et al $[62,63]$ have directly examined ${ }^{32} \mathrm{P}$ labeled mouse glucocorticoid receptors before and after transformation in intact cells and found no change in the degree of phosphorylation of the steroid-binding protein. There is also no evidence for a change in the phosphorylation state of the glucocorticoid-binding protein after thermal transformation of receptors in cytosol prepared from L cells [62]. Careful experiments have determined that the glucocorticoidbinding protein of mouse thymoma cells (WEHI-7) contains two or three phosphorylation sites per steroid binding site [61]. With this limited number of phosphorylated sites, changes at one site should be readily detectable. The results of experiments in which the ${ }^{32} \mathrm{P}$-labeled $\mathrm{L}$ cell receptor was submitted to limited proteolysis suggest that the $16 \mathrm{kD}$ trypsin fragment containing the DNA-binding domain is phosphorylated, whereas the $28 \mathrm{kD}$ fragment containing the steroid-binding domain is not [63]. At this time, however, there is no evidence to support a model in which phosphorylation of the glucocorticoid receptor, either within the DNA-binding domain or elsewhere, affects its DNA-binding activity [60-63].

Three laboratories have examined the relationship between progesterone-binding protein phosphorylation and transformation. Garcia et al [53] identified the presence of the ${ }^{32} \mathrm{P}$-labeled $110 \mathrm{kD}$ progesterone-binding protein ("B" unit) in cytosol prepared from estrogen-treated chick oviduct cells grown in the presence of [23]orthophosphate in culture. After the intact cells were incubated with progesterone, the $100 \mathrm{kD}$ binding protein could be identified in salt extracts of nuclei by immunoblot analysis, but no radioactivity could be demonstrated in the nuclear receptor. Logeat et al [52] examined the phosphorylation state of progesterone receptors in rabbit uterine slices incubated with $\left[^{32} \mathrm{P}\right]$ orthophosphate. In the absence of hormone, the cytosolic receptor was phosphorylated, but, in contrast to the observations of Garcia et al [53], in the presence of hormone, phosphorylation was markedly enhanced in receptors recovered from nuclei. Toft's laboratory (D.O. Toft, personal communication) has confirmed the observation of Logeat et al with progesterone receptors in chick oviduct minces, where exposure of cells to hormone rapidly increases the extent of phosphorylation and decreases the electrophoretic mobility of progesterone-binding protein recovered in the cytosolic fraction.

Thus it appears that association of progesterone with receptors in intact cells leads to an increase in phosphorylation of progesterone-binding proteins. The receptor is phosphorylated prior to exposure to hormone, and it appears that the increased phosphorylation in the presence of hormone is due to phosphorylation at a supplemen- 
tary site or sites. It is possible that the site(s) that is phosphorylated on the progesterone-binding protein is made available for phosphorylation when the receptor dissociates from hsp 90 . There is, as yet, no indication that phosphorylation is required for progesterone receptor transformation or that it affects the ability of the transformed receptor to bind to DNA. Indeed, Bailly et al [49] have shown that progesterone receptors isolated either from rabbit uterine cytosol before hormone-dependent phosphorylation or from nuclei after hormone-dependent phosphorylation bind with the same affinity to DNA that contains hormone-responsive elements.

\section{RECEPTOR OXIDATION AND REDUCTION IN RELATION TO RECEPTOR TRANSFORMATION}

In contrast to the data available regarding phosphorylation, it is clear that disulfide bond formation markedly affects the ability of glucocorticoid receptors to undergo $9 \mathrm{~S}$ to $4 \mathrm{~S}$ dissociation and transformation to the DNA-binding form. Sulfhydryl groups clearly play an important role in determining the functional state of glucocorticoid receptors. Sulfhydryl groups are absolutely required for maintaining the receptors in an appropriate conformation for binding of glucocorticoids [64-67]. Treatment of transformed glucocorticoid-receptor complexes with several types of sulfhydryl-modifying reagents inactivates their DNA-binding activity without causing steroid dissociation [68], and Bodwell et al [69] have provided good evidence that the sulfhydryl moieties required for DNA binding by the transformed receptor are different from those required for steroid binding by the untransformed receptor.

Using sulfhydryl-modifying reagents, it has been difficult to determine whether sulfhydryl moieties are involved in receptor dissociation and transformation. Young et al [70] reported that iodoacetamide inhibits DNA binding of glucocorticoid-receptor complexes, but, because the sulfhydryl-reacting reagent was present during the transforming procedure, it was not possible to determine whether the reagent inhibited transformation to the DNA-binding state, or whether it inhibited DNA binding by transformed receptors, or whether it inhibited both processes. Kalimi and Love [71] reexamined the question and concluded that iodoacetamide and $\mathrm{N}$-ethylmaleimide inhibited the transformation event and not DNA binding. Bodwell et al [68] were not able to reach a conclusion whether treatment of untransformed glucocorticoid-receptor complexes interferes with the transformation process.

Rather than using sulfhydryl-derivatizing agents, Tienrungroj et al [72] asked whether promoting oxidation of sulfhydryl moieties with hydrogen peroxide would inhibit the transformation event. It is clear that the presence of hydrogen peroxide during $25^{\circ} \mathrm{C}$ incubation of rat liver or $\mathrm{L}$ cell cytosols containing glucocorticoidreceptor complexes prevents conversion of receptors from $9 \mathrm{~S}$ to $4 \mathrm{~S}$ and dissociation of the receptor from hsp90. If dithiothreitol is added to reverse the peroxide effect and cytosol is incubated a second time at $25^{\circ} \mathrm{C}$, hsp90 dissociates, and the receptor is converted to the $4 \mathrm{~S}$, DNA-binding form. The transformation that occurs during the second incubation in the presence of the thiol-disulfide exchange reagent dithiothreitol is both temperature-dependent and inhibited by molybdate. These observations argue rather strongly that there are critical sulfur moieties in the untransformed receptor complex that must be in a reduced form for temperature-mediated receptor dissociation and transformation to occur. 
It should be noted that treatment of rat Dunning prostate tumor cytosol with cupric phenanthroline, a reagent that promotes disulfide bond formation, prevents dissociation of the $10 \mathrm{~S}$ receptor complex by $0.4 \mathrm{M}$ salt [73]. Similarly, peroxide prevents the dissociation of hsp90 that occurs when $\mathrm{L}$ cell glucocorticoid receptors immunoadsorbed to protein A-Sepharose are washed with $0.4 \mathrm{M} \mathrm{NaCl}$ [72]. At this time, it is not known if peroxide and cupric phenanthroline are promoting the formation of a disulfide bond(s) between the steroid-binding protein and another protein with which it is associated or whether they promote intramolecular disulfide bond formation. It is also not known whether the sulfhydryl groups required for receptor dissociation are the same as or different from those required for receptor binding to DNA. It should be noted that peroxide produces the same effects as molybdate, vanadate, and tungstate on glucocorticoid receptors.

Experiments with sulfhydryl-modifying reagents demonstrate that a sulfhydryl group (or groups) is required for binding of progesterone to receptor in chick oviduct cytosol $[74,75]$. Iodoacetamide was also shown to inhibit temperature-mediated generation of the DNA-binding state, but the experimental protocol did not unequivocally distinguish between an effect on transformation and an effect on the DNA-binding activity of the transformed receptor [75]. In 1982, MacDonald and Leavitt [76] reported that thiol-disulfide exchange reagents such as dithiothreitol promote transformation of progesterone receptors in hamster uterine cytosol. Optimal transformation (up to $75 \%$ of total steroid-bound receptor) occurred when cytosol was diluted in buffer in the presence of dithiothreitol. They suggested that the untransformed progesterone receptor was associated with an inhibitor $\left(\mathrm{M}_{r}>30,000\right)$ that dissociated from the receptor on transformation in a manner that was promoted by disulfide bond reduction. They were unable to determine whether the sulfur moieties important for transformation were located in the receptor or in the inhibitor or whether they were involved in a disulfide bridge between the two. The observations of MacDonald and Leavitt [76] might be readily explained if the redox state of the hamster uterine cytosol in the absence of reducing agent was such that a disulfide bridge could form between the steroid-binding protein and hsp 90 .

From cloning and sequencing, it is known that glucocorticoid [77] and progesterone [78] receptors (as well as all the other steroid receptors) contain multiple cysteine residues, several of which are located in the DNA-binding domain in vicinal thiol arrangements that provide optimal metal-binding ligands and sites for thioldisulfide interchange. In that various of the cysteine moieties in the receptor must be in thiol form for the untransformed receptor complex to bind steroid, for the receptor to dissociate from hsp90 during transformation, and for the transformed receptor to bind to DNA, it seems quite clear that sulfhydryl groups are critical for receptor function. The possibility that some of these functions of the receptor are naturally regulated via thiol-disulfide interchange is intriguing and deserves further research. Kaufmann et al [79] have provided evidence that glucocorticoid receptors are associated with nuclear matrix as a result of disulfide bond formation. This raises the possibility that promotion of disulfide bond formation can be used to identify proteins neighboring the transformed receptor located in nuclear acceptor sites as well as proteins neighboring the receptor in its untransformed state in the cell.

\section{INHIBITION OF RECEPTOR TRANSFORMATION BY METALS}

The group VI-A transition metal oxyanions molybdate, vanadate, and tungstate appear to inhibit glucocorticoid-receptor transformation by inhibiting the dissociation 
of the steroid-binding protein from hsp90 [30-32,80]. Although the ability of molybdate to affect glucocorticoid receptor function was discovered serendipitously during experiments in which it was being used as a phosphatase inhibitor $[2,81]$, its ability to inhibit receptor transformation is unrelated to phosphatase inhibition [see 5, for review]. This is inferred from the fact that it stabilizes receptors to dissociation by physical methods, such as by salt (eg, $\mathrm{NaCl}$, ammonium sulfate $[4,32,47,82]$ ), by alkaline $\mathrm{pH}$, and by dilution, as well as by the fact that it stabilizes highly purified progesterone and glucocorticoid receptors in their 9S form [12,13,15,16].

It is possible that molybdate interacts exclusively with the steroid-binding protein to increase its affinity for other components of the 9S complex. Alternatively, it could form some sort of bridge structure, such as that envisioned by Wilson et al [73], between the steroid-binding protein and hsp90. A concentration of $0.5-1.0 \mathrm{mM}$ molybdate or $0.2 \mathrm{mM}$ vanadate is required to produce half-maximal stabilization of untransformed glucocorticoid and progesterone receptors in cytosol at physiological $\mathrm{pH}[10,82]$, and, at these concentrations, the metal oxyanions do not affect the binding of transformed receptors to DNA. The functional groups required for molybdate interaction with the receptor are unknown. It should be noted, however, that molybdate and vanadate have a well established avidity for sulfur [83] and that they can form bridge structures between adjacent sulfhydryl moieties [84,85]. One can speculate that potential metal binding vicinal cys- $\mathrm{X}_{2}$-cys arrangements in the receptor [86] provide the ligands with which the transition metal oxyanions interact to produce their stabilizing effects. It is also interesting to speculate that molybdate, vanadate, and tungstate may stabilize the untransformed receptor by interacting with the binding site for an endogenous metal component of the untransformed receptor-hsp 90 complex.

The existence of an endogenous inhibitor of transformation was first suggested by the laboratories of Litwack et al $[87,88]$ and Milgrom et al [89], who noted that separation of glucocorticoid-receptor complexes from low- $\mathrm{M}_{\mathrm{r}}$ components of rat liver cytosol by dilution or gel filtration caused enhanced binding to nuclei and DNAcellulose. Transformation was prevented if the low- $\mathbf{M}_{\mathrm{r}}$ components were added back to the treated receptor preparation. The transformation-inhibiting factor was found to be stable to boiling and to have an $\mathrm{M}_{\mathrm{r}}$ of $<1,500$ [87-89]. Sato et al [90] subsequently reported that removal of a low- $\mathrm{M}_{\mathrm{r}}$ inhibitor by dialysis of rat uterine or ventral prostate cytosol caused estrogen and androgen receptors to transform to a state that bound to isolated nuclei. Readdition of the inhibitor prevented further transformation. These observations led to the concept that untransformed receptors in cytosol are stabilized by a low- $\mathrm{M}_{\mathrm{r}}$ endogenous factor and that, on removal of this factor, receptors are rapidly transformed.

In 1982, Leach et al [91] set up an assay in which rat liver cytosol was diluted and then returned to original volume by filtration through an Amicon filter that excludes molecules with an $M_{r}$ greater than about 10,000. In this "filtered" cytosol, high- $\mathrm{M}_{\mathrm{r}}$ components, such as the glucocorticoid receptor and hsp 90 , are present at the same concentration as in normal cytosol, but low- $\mathrm{M}_{\mathrm{r}}$, filterable components are present at about one-sixth their concentration in normal cytosol. Receptors in filtered cytosol are transformed rapidly at $15^{\circ} \mathrm{C}$, and addition of boiled rat liver cytosol inhibits the transformation in a concentration-dependent manner. Using this system, it was shown that cytosols prepared from a wide variety of rodent and human tissues, as well as from avians and amphibians and from primitive eukaryotes like lobster and yeast, all contain a heat-stable factor that inhibits the receptor transformation [91]. 
The inhibitor is effective when it is present at the concentration at which it is normally present in unfiltered cytosol. This heat-stable factor was partially purified from boiled rat liver cytosol. The factor was found to be anionic at physiological $\mathrm{pH}$ and to be unaffected by incubation with a wide variety of hydrolytic enzymes.

Meshinchi et al [92] have demonstrated that this apparently ubiquitous factor produces all the known effects of molybdate on glucocorticoid receptors. 1) It inhibits temperature- and salt-mediated receptor transformation. 2) It inhibits loss of steroidbinding activity caused by warming cytosol containing unoccupied receptors. 3) It stabilizes the oxidized, nonsteroid-binding form of the receptor to irreversible temperature-mediated inactivation of steroid binding activity. 4) It inhibits temperatureand salt-mediated dissociation of receptor to the $4 \mathrm{~S}$ form. 5) It inhibits dissociation of the receptor from hsp90. Because a substantial fraction of the bioactivity of the factor survives heating at $700^{\circ} \mathrm{F}$ for $2 \mathrm{hr}$ and all the bioactivity is eliminated by passing the factor through a column of Chelex 100 , it is highly likely that the endogenous factor is a metal. The factor behaves as a strong anion with an apparent $M_{r}$ of 340 by chromatography on Bio-Gel P-2, where it elutes in the same fractions as molybdate or vanadate. The factor binds to hydroxylapatite and is retained by a sulfhydrylcellulose matrix. The latter may indicate that the metal anion has an avidity for sulfur, although this has not been proved; it has not yet been determined if derivatization of the sulfhydryl moieties prevents adsorption of the factor to the column matrix.

Thus the endogenous factor not only produces all the known effects of molybdate and vanadate on receptor function but it also has the same size, charge, and chelation properties as these metal oxyanions. Because the receptor dissociates rapidly when cytosol is depleted of the factor, it is reasonable to propose that the factor normally interacts with the receptor to account for the stability of the large- $\mathrm{M}_{\mathrm{r}}$, untransformed complex in cytosol preparations. It is not an unreasonable speculation that molybdate and vanadate affect steroid-receptor complexes by interacting with a metal anion binding site that is normally occupied by this endogenous receptorstabilizing factor. In the model shown in Figure 1, it is indicated that cysteine moieties in the steroid-binding protein may contribute the ligands that determine such a metal anion-binding site.

\section{SOME THOUGHTS REGARDING THE RECEPTOR-hsp90 COMPLEX}

Although a complex between hsp90 and steroid receptors can be readily demonstrated in cell-free lysates, it has not been proved that the existence of the complex is relevant to hormone action in intact cells. Some investigators have questioned whether the complex with the heat shock protein is an artifact resulting from the use of steroid-affinity resins [93] or from the use of molybdate to stabilize receptors in their 9S, untransformed state [94]. Several observations argue against such an artifact. 1) The complex has been demonstrated by immunological as well as steroid-affinity methods $[27,28,30] .2$ ) Steroid receptors were demonstrated to exist as 9S complexes in cell-free lysates many years prior to the discovery of molybdate effects [95]. Molybdate stabilizes receptors in their $9 \mathrm{~S}$ form but does not promote the formation of $9 \mathrm{~S}$ complexes from the dissociated $4 \mathrm{~S}$ form. 4) Although molybdate is helpful, it is not required to visualize the complex between hsp90 and either the progesterone $[27,40,96]$ or the glucocorticoid receptor [62]. 5) Molybdate has been shown to inhibit nuclear accumulation of glucocorticoid- and estrogen-receptor complexes in 
intact cells while simultaneously increasing the recovery of the $9 \mathrm{~S}$ complex [97]. The latter observation, combined with the observation that dissociation of glucocorticoid receptors from hsp90 is promoted by hormone in intact cells [22], supports the intracellular existence and physiological relevance of a receptor-hsp90 complex.

A major problem in determining the physiological relevance of steroid-receptor association with hsp90 is that the function of this ubiquitous and abundant cytoplasmic protein is unknown $[98,99]$. The rate of its synthesis is increased by heat shock [100], and its synthesis is depressed during glucose deprivation [101]. It is interesting to note that, in L cells deprived of glucose, glucocorticoids selectively increase the rate of hsp90 synthesis [102]. Although it is normally located in the cytoplasm, hsp89 (the avian homolog of the mammalian hsp90) becomes associated with the nucleus when heat-shocked chick embryo cells are restressed [99]. This association with nuclear structure is noncovalent, since it is completely disrupted by mild detergent lysis [99]. These observations with the avian heat shock protein raise the possibility that mammalian hsp90 is associated with structural components of the cell and is subject to similar relocation. In this respect, it is interesting to note that hsp90 has the ability to bind to purified $\mathrm{F}$-actin in a $\mathrm{Ca}^{2+}$-calmodulin-regulated manner $[103,104]$, suggesting that it might associate with an actin-containing structure(s) in intact cells.

The fact that hsp90 exists in cells from primitive eukaryotes to humans and is part of the heat shock response suggests a function essential to cell survival $[41,42]$. In that hsp90 is present in great abundance with respect to steroid receptors, it is clear that it must perform a more general function in the regulation of cellular events. It is known that the Rous sarcoma virus tyrosine kinase pp $60^{\mathrm{src}}$ binds transiently to hsp 90 $[105,106]$, as do some other avian sarcoma virus-transforming proteins $[107,108]$. The reason for this association is not known, but it is interesting that a temperaturesensitive mutant $\mathrm{pp} 60^{\mathrm{src}}$ binds with high affinity to hsp90 at nonpermissive temperature. The complex of pp60 $60^{\text {src }}$ with hsp90 includes a third protein of $M_{r} 50,000$ whose function is unknown.

As has been noted above and elsewhere [96], there is a distinct possibility that the 9S steroid receptor complex contains another component or components. It is important to note that a monoclonal antibody prepared against the molybdate-stabilized 9S rabbit progesterone receptor recognizes an epitope on a $59 \mathrm{kD}$ protein $[109,110]$. The $59 \mathrm{kD}$ protein appears to be associated with hsp90, and the antibody against the $59 \mathrm{kD}$ protein causes the immunospecific absorption of androgen, estrogen, glucocorticoid, and progesterone receptors from rabbit uterine or liver cytosol [111]. Peptide mapping suggests that the $59 \mathrm{kD}$ protein is a protein structurally different from hsp90, raising the possibility that it is a third component of $9 \mathrm{~S}$ steroidreceptor complexes.

If steroid receptors interact with hsp90 in a physiologically significant way in intact cells, then it should be possible to mutate receptor genes and alter both steroid response and association with hsp90. Giguere et al [112] have constructed a variety of insertional mutants of the human glucocorticoid-receptor gene that have permitted the definition of at least four functional domains in the receptor protein. If the association of receptor with hsp90 is important for maintaining the receptor in an inactive form in the absence of hormone in intact cells, then one can predict that at least one structural feature required for high-affinity association with hsp90 lies within the steroid-binding domain. Three observations support this prediction. 1) Gehring and Arndt [113] have demonstrated that glucocorticoid receptors of the $\mathrm{nt}^{1}$ type from 
a steroid-resistant mutant line of S49.1 lymphoma cells exist in their untransformed, molybdate-stabilized state as $9 \mathrm{~S}$ complexes. The $\mathrm{nt}^{1}$ receptor consists of the carboxylterminal $40 \mathrm{kD}$ peptide, which contains both the steroid-binding and DNA-binding domains [114]. Gehring and Arndt [113] also demonstrated that incubation of molybdate-stabilized, wild-type $\$ 49$ cell receptors with chymotrypsin yields $9 \mathrm{~S}$ complexes in which the steroid-binding protein has been cleaved to about $40 \mathrm{kD}$. Mendel et al [115] have made similar observations with receptors in rat thymocyte cytosol. It may be inferred from these observations that the $40 \mathrm{kD}$ carboxyl portion of the steroidbinding protein is sufficient for creating the $9 \mathrm{~S}$ heteromeric complex [113], and it is not likely that the $50 \mathrm{kD}$ amino segment plays a critical role in recognizing hsp90. 2) Miesfeld et al [116] have demonstrated that carboxyl-terminal deletions of the rat glucocorticoid-receptor gene produce receptors that no longer require hormone binding for enhancer activation. Thus these truncated receptors, which lack the steroidbinding domain, function as constitutive activators. If association with hsp90 maintains the receptor in an inactive form in the absence of hormone, then a site that is responsible for determining the receptor-hsp90 complex must lie somewhere within (or very near) the steroid-binding domain. 3) If the model is a general one in the sense that hsp90 associates with a variety of steroid receptors, then the receptors should contain a common structural feature within the steroid-binding domain. As was noted by Danielson et al [117], there is a 20 -amino-acid region of strong homology that lies within the C-terminal domain of the mouse glucocorticoid receptor (amino acids 583-602) and the human estrogen receptor (361-380). The same region exists between amino acids 729 and 748 of the rabbit progesterone receptor [118]. Danielson et al [117] have speculated that this region is involved in receptor transformation and that alterations in the region might result in a receptor that does not associate with hsp90 and is transcriptionally active in the absence of hormone.

One of the more intriguing questions raised by the model presented in Figure 1 relates to how hormone binding might trigger dissociation of the receptor-hsp 90 complex. It is possible that the binding of the steroid changes the confirmation of the receptor in the region that determines binding to hsp90. Another possibility is that the steroid indirectly alters the affinity of the receptor for hsp90 by affecting the binding site for an endogenous metal anion that stabilizes the receptor-hsp90 complex. As is indicated in the model, when an endogenous metal anion is removed from cytosol, the glucocorticoid receptor dissociates from hsp90. The binding of the steroid might reduce the affinity of the steroid-binding protein for the metal component through an allosteric mechanism or possibly by affecting the redox state of the metal-binding ligands.

If the association of the glucocorticoid receptor with hsp90 in the intact cell determines whether the receptor is subsequently recovered in the cytosolic or nuclear fraction after cell lysis, then a recent experiment by Mendel et al [119] suggests that dissociation from hsp90 can occur in the absence of hormone. It has been known for many years that cells exposed to energy-limiting conditions, such as glucose limitation and anaerobiosis, rapidly lose their ability to bind glucocorticoids [120-122]. Both the loss of binding capacity and its recovery when the metabolic blockade is overcome are unaffected by inhibitors of protein synthesis $[82,122]$, implying that receptor turnover is not responsible for the loss and return of steroid-binding capacity. It was assumed that the receptor was probably present in a nonhormone-binding state in cytosol prepared from such ATP-depleted cells. Using the Western blot procedure, 
Mendel et al [119] have shown that glucocorticoid receptors become tightly bound to nuclei when mouse thymoma cells are depleted of ATP by treatment with dinitrophenol in the absence of hormone. It is not clear how this shift of receptor to the nuclear fraction occurred. It may be that the effects of dinitrophenol on cellular metabolism somehow disrupted the receptor-hsp90 complex and the receptor was then able to associate with normal nuclear "acceptor" sites, or it may be that the effects of dinitrophenol treatment provoked the formation of disulfide bonds between the receptor and nuclear components or between the receptor and cellular structural elements that are recovered in the nuclear fraction. Exposure of cells to dinitrophenol is an excellent method of generating a heat shock response [42], and the change in receptor localization could be related in some way to the cellular stress response. At this time, it is possible that the observation of Mendel et al [119] reflects hormone-free transformation of glucocorticoid receptors in intact cells.

\section{ACKNOWLEDGMENTS}

I thank Jack-Michel Renoir for reading and commenting on the manuscript and David Toft and Milton Schlesinger for their helpful discussion and collaboration.

This author's research is supported by grant CA 28010 from the National Cancer Institute and grant AM 31573 from the National Institutes of Health.

\section{REFERENCES}

1. Schmidt TJ, Litwack G: Physiol Rev 62:1131-1192, 1982.

2. Nielsen CJ, Sando JJ, Vogel W, Pratt WB: J Biol Chem 252:7568-7578, 1977.

3. Toft DO, Nishigori H: J Steroid Biochem 11:413-416, 1979.

4. Leach KL, Dahmer MK, Hammond ND, Sando JJ and Pratt WB: J Biol Chem 254:11884-11890, 1979.

5. Dahmer MK, Housley PR, Pratt WB: Annu Rev Physiol 46:67-81, 1984.

6. Sherman MR, Stevens J: Annu Rev Physiol 46:83-105, 1984.

7. Holbrook NJ, Bodwell JE, Jeffries M, Munck A: J Biol Chem 258:6477-6485, 1983.

8. Sherman MR, Moran MC, Tuazon FB, Stevens YW: J Biol Chem 258:10366-10377, 1983.

9. Vedeckis WV: Biochemistry 22:1983-1989, 1983.

10. Nishigori H, Toft DO: Biochemistry 19:77-83, 1980.

11. Dougherty JJ, Toft DO: J Biol Chem 257:3113-3119, 1982.

12. Renoir JM, Yang CR, Formstecher P, Lustenberger P, Wolfson A, Redeuilh G, Mester J, RichardFoy H, Baulieu EE: Eur J Biochem 127:71-79, 1982.

13. Puri RK, Grandics P, Dougherty JJ, Toft DO: J Biol Chem 257:10831-10837, 1982.

14. Housley PR, Pratt WB: J Biol Chem 258:4630-4635, 1983.

15. Grandics P, Miller A, Schmidt TJ, Mittman D, Litwack G: J Biol Chem 259:3173-3180, 1984.

16. Idziorek T, Formstecher P, Danze PM, Sablonniere B, Lustenberger P, Richard C, Dumur V, Dautrevaux M: Eur J Biochem 153:65-74, 1985.

17. Renoir JM, Buchou T, Mester J, Radanyi C, Baulieu EE: Biochemistry 23:6016-6023, 1984.

18. Dougherty JJ, Puri RK, Toft DO: J Biol Chem 259:8004-8009, 1984.

19. Schrader WT, Birnbaumer ME, Hughes MR, Weigel NL, Grody WW, O'Malley BW: Rec Prog Horm Res 37:583-629, 1981.

20. Renoir JM, Buchou T, Baulieu EE: Biochemistry 25:6405-6413, 1986.

21. Housley PR, Sanchez ER, Westphal HM, Beato M, Pratt WB: J Biol Chem 260:13810-13817, 1985.

22. Mendel DB, Bodwell JE, Gametchu B, Harrison RW, Munck A: J Biol Chem 261:3758-3763, 1986.

23. Wrange O, Okret S, Radojcic M, Carlstedt-Duke J, Gustafsson JA: J Biol Chem 259:4534-4541, 1984. 
24. Radanyi C, Joab I, Renoir JM, Richard-Foy H, Baulieu EE: Proc Natl Acad Sci USA 80:2854$2858,1983$.

25. Renoir JM, Mester J, Buchou T, Catelli MG, Touhimaa P, Binart N, Joab I, Radanyi C, Baulieu EE: Biochern J 217:685-692, 1984.

26. Touhimaa P, Renoir JM, Radanyi C, Mester J, Joab I, Buchou T, Baulieu EE: Biochem Biophys Res Commun 119:433-439, 1984.

27. Sullivan WP, Vroman BT, Bauer VJ, Puri RK, Riehl RM, Pearson GR, Toft DO: Biochemistry 24:4214-4222, 1985.

28. Joab I, Radanyi C, Renoir JM, Buchou T, Catelli MG, Binart N, Mester J, Baulieu EE: Nature 308:850-853, 1984.

29. Oblin ME, Lombes M, Radanyi C, Baulieu EE: In: Proc 6th Int Symp J Steroid Biochem, Paris, May, 1987. In press.

30. Sanchez ER, Toft DO, Schlesinger MJ, Pratt WB: J Biol Chem 260: 12398-12401, 1985.

31. Sanchez ER, Housley PR, Pratt WB: J Steroid Biochem 24:9-18, 1986.

32. Sanchez ER, Meshinchi S, Tienrungroj W, Schlesinger MJ, Toft DO, Pratt WB: J Biol Chem 262:6986-6991, 1987.

33. Sanchez ER, Meshinchi S, Schlesinger MJ, Pratt WB: J Steroid Biochem (in press).

34. Riehl RM, Toft DO: J Biol Chem 259:15324-15330, 1984.

35. Riehl RM, Toft DO, Meyer MD, Calson GL, McMorris TC: Exp Cell Res 153:544-549, 1984.

36. Riehl RM, Sullivan WP, Vroman BT, Bauer VJ, Pearson GR, Toft DO: Biochemistry 24:6586$6591,1985$.

37. Gasc JM, Renoir JM, Radanyi C, Joab I, Tuohimaa P, and Baulieu EE: J Cell Biol 99:1193-1201, 1984.

38. Dougherty JJ, Puri RK, Toft DO: J Biol Chem 257:14226-14230, 1982.

39. Grandics P, Miller A, Schmidt TJ, Litwack G: Biochem Biophys Res Commun 120:59-65, 1984.

40. Catelli MG, Binart N, Jung-Testas I, Renoir JM, Baulieu EE, Feramisco JR, Welch WJ: EMBO J 4:3131-3135, 1985.

41. Schlesinger MJ, Ashburner M, Tissieres A (eds): "Heat Shock from Bacteria to Man." Cold Spring Harbor, NY: Cold Spring Harbor Laboratory, 1982.

42. Craig E: CRC Crit Rev Biochem 18:239-280, 1985.

43. Schuh S, Yonemoto W, Brugge J, Bauer VJ, Riehl RM, Sullivan WP, Toft DO: J Biol Chem 260: 14292-14296, 1985.

44. Okret S, Wilkstrom AC, Gustafsson JA: Biochemistry 24:6581-6586, 1985.

45. Moguilewsky M, Philibert D: J Steroid Biochem 20:271-276, 1984.

46. Baulieu EE, Segal SJ (eds): "The Antiprogestin Steroid RU486 and Human Fertility Control." New York: Plenum, 1985.

47. Dahmer MK, Quasney MW, Bissen ST, Pratt WB: J Biol Chem 256:9401-9405, 1981.

48. Willmann T, Beato M: Nature 324:688-691, 1986.

49. Bailly A, LePage C, Rauch M, Milgrom E: Nature 5:3235-3241, 1986.

50. Becker PB, Gloss B, Schmid W, Strahle U, Schutz G: Nature 324:686-688, 1986.

51. Raaka BM, Samuels HH: J Biol Chem 258:417-425, 1983.

52. Logeat F, LeCunff M, Pamphile R, Millgrom E: Biochem Biophys Res Commun 131:421-427, 1985.

53. Garcia T, Jung-Testas I, Baulieu EE: Proc Natl Acad Sci USA 83:7573-7577, 1986.

54. Munck A, Leung K: In Pasqualini JR (ed): "Receptors and Mechanism of Action of Steroid Hormones." New York: Dekker, 1977, pp 311-397.

55. Sando JJ, Hammond ND, Stratford CA, Pratt WB: J Biol Chem 254:4779-4789, 1979.

56. Barnett CA, Schmidt TJ, Litwack G: Biochemistry 19:5446-5455, 1980.

57. Reker CE, Kovacic-Milivojevic B, Eastman-Reks SB, Vedeckis WV: Biochemistry 24:196-204, 1985.

58. Wilcox KW, Kohn A, Sklyanskaya E, Roizman B: J Virol 33:167-182, 1980.

59. Klein H, Maltzman W, Levine AJ: J Biol Chem 254:11051-11060, 1979.

60. Smith AC, Elasser MS, Harmon JM: J Biol Chem 261:13285-13292, 1986.

61. Mendel DB, Bodwell JE, Munck A: J Biol Chem 262:5644-5648, 1987.

62. Tienrungroj W, Sanchez ER, Housley PR, Harrison RW, Pratt WB: Submitted for publication.

63. Sanchez E, Tienrungroj W, Dalman FC, Lin AL: J Steroid Biochem (in press).

64. Koblinski M, Beato M, Kalimi M, Feigelson P: J Biol Chem 247:7897-7904, 1972. 
65. Rees AM, Bell PA: Biochim Biophys Acta 411:121-132, 1975.

66. Grippo JF, Tienrungroj W, Dahmer MK, Housley PR, Pratt WB: J Biol Chem 258:13658-13664, 1983.

67. Grippo JF, Holmgren A, Pratt WB: J Biol Chem 260:93-97, 1985.

68. Bodwell JE, Holbrook NJ, Munck A: Biochemistry 23:1392-1398, 1984.

69. Bodwell JE, Holbrook NJ, Munck A: Biochemistry 23:4237-4242, 1984.

70. Young HA, Parks WP, Scolnick EM: Proc Natl Acad Sci USA 72:3060-3064, 1975.

71. Kalimi M, Love K: J Biol Chem 255:4687-4690, 1980.

72. Tienrungroj W, Meshinchi S, Sanchez ER, Pratt SE, Grippo JF, Holmgren A, Pratt WB: J Bio Chem 262:6992-7000, 1987

73. Wilson EM, Wright BT, Yarborough WG: J Biol Chem 261:6501-6508, 1986.

74. Coty WA: J Biol Chem 255:8035-8037, 1980.

75. Kalimi M, Banerji A: J Steroid Biochem 14:593-597, 1981.

76. MacDonald RG, Leavitt WW: J Biol Chem 257:311-315, 1982.

77. Hollenberg SM, Weinberger C, Ong ES, Cerelli G, Oro A, Lebo R, Thompson EB, Rosenfeld MG, Evans RM: Nature 318:635-641, 1985.

78. Jeltsch JM, Krozowski Z, Quirin-Stricker C, Gronemeyer H, Simpson RJ, Garnier JM, Krust A, Jacob F, Chambon P: Proc Natl Acad Sci USA 83:5424-5428, 1986.

79. Kaufmann SH, Okret S, Wikstrom AC, Gustafsson JA, Shaper JH: J Biol Chem 261:11962-11967, 1986.

80. Sanchez ER, Tienrungroj W, Meshinchi S, Bresnick EH, Pratt WB: In Spelsberg T, Kumar R (eds): "Sterol/Steroid Hormone Action." Amsterdam: Martinus Nijhoff (in press).

81. Nielsen CJ, Vogel WM, Pratt WB: Cancer Res 37:3420-3426, 1977.

82. Wheeler RH, Leach KL, LaForest AC, O'Toole TE, Wagner R, Pratt WB: J Biol Chem 256:434441, 1981.

83. Dieman E, Muller A: Coord Chem Rev 10:79-122, 1973

84. Weathers BJ, Grate JH, Schrauzer GN: J Am Chem Soc 101:917-924, 1979.

85. Kay A, Mitchel PCH: Nature 219:267-268, 1968.

86. Berg JM: Science 232:485-487, 1986.

87. Cake MH, Goidl JA, Parchman LG, Litwack G: Biochem Biophys Res Commun 71:45-52, 1976.

88. Goidl JA, Cake MH, Dolan KP, Parchman LG, Litwack G: Biochemistry 16:2125-2130, 1977.

89. Bailly A, Sallas N, Milgrom E: J Biol Chem 252:858-863, 1977.

90. Sato B, Noma K, Nishizawa Y, Nakao K, Matsumoto K, Yamamura Y: Endocrinology 106: 1142 1148, 1980.

91. Leach KL, Grippo JF, Housley PR, Dahmer MK, Salive ME, Pratt WB: J Biol Chem 257:381$388,1982$.

92. Meshinchi S, Grippo JF, Sanchez ER, Martell KJ, Pratt WB: Submitted for publication.

93. Birnbaumer M, Bell RC, Schrader WT, O’Malley BW: J Biol Chem 259:1091-1098, 1984.

94. King RJB: J Steroid Biochem 25:451-454, 1986.

95. Gorski J, Toft DO, Shyamala G, Smith D, Notides A: Rec Prog Horm Res 24:45-80, 1968.

96. Renoir JM, Baulieu EE: In Spelsberg T, Kumar R (eds): “Sterol/Steroid Hormone Action." Amsterdam: Martinus Nijhoff (in press).

97. Raaka BM, Finnerty M, Sun E, Samuels HH: H Biol Chem 260:14009-14015, 1985.

98. Welch WJ, Garrels JI, Thomas GP, Lin JJC, Feramisco JR: J Biol Chem 258:7102-7111, 1983

99. Collier NC, Schlesinger MJ: J Cell Biol 103:1495-1507, 1986.

100. Kelley PM, Schlesinger MJ: Cell 15:1277-1286, 1978.

101. Kasambalides EJ, Lanks KW: Exp Cell Res 132:31-39, 1981

102. Kasambalides EJ, Lanks KW: I Cell Physiol 114:93-98, 1983.

103. Koyasu S, Nishida E, Kadowaki T, Matsuzaki F, Iida K, Harada F, Kasuga M, Sakai H, Yahara I: Proc Natl Acad Sci USA 83:8054-8058, 1986.

104. Nishida E, Koyasu S, Sakai H, Yahara I: J Biol Chem 261:16033-16036, 1986.

105. Brugge JS, Erickson E, Erickson RL: Cell 114:93-98, 1983.

106. Lanks KW, Kasambalides EJ, Chinkers M, Brugge JS: J Biol Chem 257:8604-8607, 1982.

107. Opperman H, Levinson W, Bishop JM: Proc Natl Acad Sci USA 78:1067-1071, 1981.

108. Lipsich LA, Cutt JR, Brugge JS: Mol Cell Biol 2:875-880, 1982.

109. Nakao K, Myers JE, Faber LE: Can J Biochem Cell Biol 63:33-40, 1985.

110. Tai PKK, Faber LE: Can J Biochem Cell Biol 63:41-49, 1985. 


\section{8:JCB Pratt}

111. Tai PKK, Maeda Y, Nakao K, Wakim NG, Duhring JL, Faber LE: Biochemistry 25:5269-5275, 1986.

112. Giguere V, Hollenberg SM, Rosenfeld MG, Evans RM: Cell 46:645-652, 1986.

113. Gehring U, Arndt H: FEBS Lett 179:138-142, 1985.

114. Gehring U, Holtz A: Biochemistry 22:4013-4018, 1983.

115. Mendel DB, Holbrook NJ, Bodwell JE: J Biol Chem 260:8736-8740, 1985.

116. Miesfeld R, Godowski P, Yamamoto KP: J Cell Biochem Suppl 11A:88, 1987.

117. Danielsen M, Northrup JP, Ringold GM: EMBO J 5:2513-2522, 1986.

118. Loosfelt H, Atger M, Misrahi M, Guichon-Mantel A, Meriel C, Logeat F, Benarous R, Milgrom E: Proc Natl Acad Sci USA 83:9045-9049, 1986.

119. Mendel DB, Bodwell JE, Munck A: Nature 324:478-480, 1986.

120. Munck A, Brinck-Johnsen T: J Biol Chem 243:5556-5565, 1968.

121. Munck A, Wira C, Young DA, Mosher KM, Hallahan C, Bell PA: J Steroid Biochem 3:567-578, 1972.

122. Bell PA, Munck A: Biochem J 136:97-107, 1973. 